Journal of Academic Value Studies

Available online at http://javstudies.com ISSN: $2149-8598$

\title{
Kalite Yönetimi Perspektifinde Sağlık Hizmetleri
}

\author{
Health Services in the Perspective of Quality Management
}

\author{
Ebru Köktepe Karahüseyinoğlu*1(D) \\ ${ }^{1}$ Researcher in Health Management
}

\begin{abstract}
Received: 22.08 .2021
Accepted: 28.09.2021

This article was checked by intihal.net

Öz

İnsanoğlu var olduğu zaman dilimi içeresinde her zaman kendisine en iyisini düşünmüş ve bu yaklaşım değişimin başlangıç noktası olmuştur. Her zaman konforu ön planda tutan insan tüm yaşamı boyunca gelişmeye devam etmektedir. Bu gelişim ve değişim insanın doğası gereği her zaman olacaktır. Bir insanın gelişimine katkı sağlayacak olan etmenlerin, nitelikli ve kaliteli olması üzerinde önemle durulmaktadır. Kalite, değişim, gelişim, reform ve yeniden yapılanma kavramlar ile yakından ilgilidir.

Kalite kavramı bir mal ve hizmetin dayanıklılı̆ını güvenilirliğini ölçmek için kullanılmıştır. Bu bakımdan kalite ve kaliteli olgusu da tüm gelişim sürecinin yanında var olmuştur. Bir ürünün kaliteli olması diğer benzer ürünlerden farkını ortaya koymaktadır. Bu bakımdan kalite önemli bir pazarlama ve tercih edilme sistemi oluşturmuştur. Bu durum her sektör için benzer şekilde bir süreç meydana getirmiştir.

Kalite yönetimi son zamanlarda oldukça önem verilen bir alandır. Sağılk alanında kalite yönetimi ve kaliteli hizmet standartlarının oluşması kaçınılmazdır. Sağ ık hizmetlerinde kalitenin geliştirilmesi; tüketiciler, hizmet sunanlar ve bütün toplum için önem taşımaktadır. Sağlık sektöründe meydana gelen dinamik değişimler, sağlık hizmetlerinde kalite hareketinin ortaya çıkmasına katkı sunmuştur. Çalışma sağlık hizmetlerinde kalite yönetiminin yeri ve bunu uygulayan kurumların sağlayacağı yararlara dikkat çekmek maksadıyla yapıımış bir derleme olarak nitelendirilebilir.
\end{abstract}

Anahtar Kelimeler: Sağlık Hizmetleri, Kalite Yönetimi, Toplam Kalite Yönetimi, Sağlık Hizmetlerinde Kalite Yönetimi

\section{Abstract}

Mankind has always thought of the best for itself in the time period it has existed, and this has been the starting point of development and change. The human being, who always prioritizes comfort, develops and continues to develop throughout his entire life. This development and change has always been and will be due to the nature of human beings.

The concept of quality has been used to measure the durability and reliability of a good or service. In this respect, the concept of quality and quality has existed alongside the entire development process. In this respect, quality has created an important marketing and preference system. This has created a similar process for each sector.

Quality management is an area that has received a lot of attention recently. It is inevitable to establish quality management and quality service standards in the field of health. Improving quality in health services; It is important for consumers, service providers and society as a whole. Dynamic changes in the health sector contributed to the emergence of the quality movement in health services. The study can be described as compilation made in order to draw attention to the place of quality management in health services and the benefits of the institutions that implement it.

Keywords: Health Services, Quality Management, Total Quality Management, Quality Management in Health Services

Karahüseyinoğlu, E.K. (2021). Kalite Yönetimi Perspektifinde Sağlık Hizmetleri. Journal of Academic Value Studies, 7(3), $394-402$. http://dx.doi.org/10.29228/javs.52422

\footnotetext{
*E-mail address: ebrukoktepe23@gmail.com
} 


\section{Giriş}

Mal ve hizmetler denilince akla gelen ilk şey insanların ihtiyaçlarını karşılamak için ürettikleri şeyler olarak değerlendirilir. İhtiyaç ise karşılandığında haz ve doyum veren, karşılanmadığında elem ve keder hissettiren bir kavramdır. Bu bakımdan insanlar kendi yaşamlarını kolaylaştırmak ve güvende olmak için daha kaliteli ürün ve hizmetleri tercih ederler. İşte bu noktada tercih sebebi olan kalite kavramı ortaya çıkmaktadır.

Sağlık hizmetleri verilirken sağlık kurumlarının kalitesi de ölçülebilir. Bunu ölçmek için hasta memnuniyeti anketleri veya benzer uygulamalar yapılabilir. Sağıık kurumlarının kaliteli olması insan hayatını kolaylaştıran ve kişinin kendisini güvende hissetmesini sağlayan bir yönü vardır.

Sağlık hizmetleri kapsamında, kişiler tanı ve tedavi süreçlerini; kendilerini hastalıklarının en iyi uzmanı olan hekime ya da ameliyat olacaklarsa o alanda başarılı olan cerraha yada bir ilaç kullanacaklarsa o ilacı üreten ülkeye veya işletmeye duyulan güven ile kalite arasındaki bağı öngörerek devam ettirirler. Sağlık hizmetlerinde kalite yönetimi kavramı bu nokta da ortaya çıkmaktadır.

Sağlık hizmetlerinde standart belirmek oldukça zordur. Bunun nedeni her hasta için farklı uygulamaların yapılmasıdır. Ancak ayakta tedavi yatarak tedavi gibi ya da aynı hastalık ve şikayetten gelenlerin sorunlarının daha hızı çözülmesi adına belirli gruplamalar yapılarak uygulamalar standardize edilebilir ve kalite yönetimi oluşturulabilir.

Sağlık hizmetlerinde kalite yönetimi sağlık kurumlarının başarısını verimliliğini artıracak aynı zamanda kurum için rekabet ortamında önemli bir avantaj sağlayacaktır. Ayrıca, kalite yönetimi hasta ve hasta yakınlarının güvende hissetmelerine ve sağlıklarına kavuşmalarına katkı sağlayacaktır.

Çalışmamızda sağlık hizmetlerine, sağlık kurumlarının görev ve özelliklerine değinilerek kalite yönetimi kavramı, toplam kalite kavramları tanımlanmış ve sağık hizmetleri açısından ele alınmıştır. Ayrıca kalite yönetimi uygulanmasının sağlık kurumlarına ne tür yararları olduğu değerlendirilmiştir.

\section{Sağlık Hizmetleri ve Sınıflandırılması}

Dünya sağlık örgütüne göre sağlık hizmeti, hastalık halinde tanı ve tedavilerin uygulanması ve bu işlemler yapılırken sağlığın korunmasını kapsamaktadır. Aynı zaman da kişinin sağlığı bozulmadan da sağlık risklerine karşı uyarılmalıdır bunun için sunulan hizmetlere sağlık hizmeti denir. Koruyucu tedavi edici ve rehabilitasyon hizmetlerinin tümünü kapsar(Akdur,1999:5).

Başka bir tanıma göre: insanların sağlığını tehdit eden yâda edebilecek unsurların ortadan kaldırıması, insanların bu olumsuz durumdan etkilenmesinin önüne geçilmesi, hastalık halinde tedavi edici her türlü hizmetin verilmesidir(Sağlık Bakanlığı, 2019).Örnek verecek olursak ; sağlık kurumları yani hastaneler , aile sağlığı merkezleri, acil merkezleri, toplum sağlığı merkezleri buralarda insanlara hizmet edilir. Bir bebeğin aşısı yapılır ve bu geleceğe yönelik koruma hizmeti olarak karşımıza çıkar. Ayağı kırılan bir kişiye alçı ve ameliyat ya da başka tedaviler uygulanır bu kişiye özel bir tedavi hizmetidir. Kalbi duran bir hasta hayata döndürülür bu da kişiye özel müdahaleye girebilir bir durumdur. Işte buradan da anlaşıldığı üzere sağlık hizmetleri kademeli olarak insanların intiyaçlarına göre belirlenir. Bu ihtiyaçlar bazen hafif ayakta tedavi gerektirirken bazen de uzun süreli hastanede yatışlara neden olabilir işte burada mesele bu hizmetin bir standart belirlenerek verilmesidir.Kalite yönetimi süreci söz konusu sağlık hizmetleri için önemlidir. Çünkü olaylar belirsiz olsa da hasta memnuniyeti süreci belirlidir.

Sağlık hizmetleri koruyucu sağlık hizmetleri, tedavi edici sağlık hizmetleri, rehabilitasyon hizmetleri ve sağlığın geliştirilmesi hizmetleri olmak üzere dört grupta sınıflandırılmaktadır.

\subsection{Koruyucu Sağlık Hizmetleri}

Sağlık hizmetlerinin en temel vazifesi insanları hastalıklardan korumaktır. Koruyucu sağılık hizmetleri çevre düzenlenmesi, aile planlaması, yetersiz beslenmenin önlenmesi, bulaşıcı hastalıkların yayılmaması ve insanların hastalıklardan kurtulması için önlem tedbir ve bilgilendirme yapar. Bu hizmetleri sağlık bakanlığı tüm bireylere koşulsuz şartsız sunmaktadır(Erdem,2007:61).

\subsection{Tedavi Edici Sağlık Hizmetleri}

Tedavi hizmetleri sağlık durumu bozulan bireylerin, eski durumlarına gelmelerini sağlamak maksadıyla verilen hizmetlerdir. Tedavi edici hizmetler hekim sorumluluğu dahilinde, diğer sağılk çalışanlarının da destekleri ile sürdürülür. Tedavi edici hizmetler, ilk poliklinik müdahalesi ve yatan hastalarla dışarıdan gelen hastaların klinik müdahale hizmetleri de dâhil olmak üzere, hastalara muayenehaneler ve sağlık kuruluşlarında verilen tüm tedavi edici 
hizmetleri ve bu tedaviye bağı olarak hastanın satın aldığı tüm ilaç ve sağlık gereçlerini kapsamaktadır (Kurtulmuş, 1998: 84). Tedavi edici sağlık hizmetleri, hizmetin kapsam ve yoğunluğu dikkate alınarak sınıflandırılmıştır (Tengilimoğlu vd., 2012: 47-48).Bunlar :

Birinci Basamak Tedavi Hizmetleri: Birinci basamak sağılk hizmeti sunan kurumlar, sağlık hizmeti talebinde bulunan kişilerin ilk başvurdukları kuruluşlardır. Toplumdaki aileler ve bireylere bir bütün olarak ulaşabilen, toplumdaki sağlık sorunlarına çözüm bulmaya yönelik gerçekleştirilen faaliyetler birinci basamak sağlık hizmetleri içerisinde yer alır (Çetin, 2015: 10). Hastalıkların evde ya da ayakta teşhis ve tedavisi için düzenlenen hizmetlerdir ve hastaların tedavisi için yatarak tedavinin gerekli olmadığı, genellikle koruyucu ve iyileştirici sağlık hizmetleridir. Ülkemizde birinci basamak sağlık hizmetlerini 112 Acil Yardım İstasyonları, Kanser Erken Teşhis Tarama ve Eğitim Merkezleri (KETEM), Verem Savaş Dispanserleri, Toplum Sağlığı Merkezleri, Ana Çocuk Sağlığı ve Aile Planlaması Merkezleri, Aile Sağlığı Merkezleri ve Sağlık ocakları vermektedir (Kıraç,2019: 30).

ikinci Basamak Tedavi Hizmetleri: Tıbbi bilgi ve teknoloji açısından aşırı donanım istenmeyen hastalıkların belirlenmesi ve yatarak tedavi gerçekleştirilmesi için verilen hizmetlerdir. Genel hastaneler ve yataklı merkezler ülkemizde bu tür hizmetlerin verildiği sağlık kuruluşlarıdır. Eğitim ve araştırma hastanesi pozisyonunda olmayan devlet hastaneleri ve dal hastaneleri ile bu hastanelere bağlı semt poliklinikleri, ağız ve diş sağlığı hastaneleri, entegre ilçe hastanesi, kamu kurumlarına ait olup Bakanlıkça ruhsatlandırılmış olan hastaneler, tıp merkezleri ve dal merkezleri gibi birinci basamaktan sevk alınarak ya da doğrudan başvurunun mümkün olduğu tedavi kurumlarıdır (Sert,2019: 31).

Üçüncü Basamak Tedavi Hizmetleri: Bazı durumlarda hastalık ilerlemiş ya da sağlık kuruluşuna başvuran vakanın durumu çok ağır olabilir, bu gibi durumlarda ikinci basamak yeterli gelmez, hastalık uzmanlaşmaya dayalı bir tedavi ve bakım gerektirebilir. Böyle bir durumda sağlık problemi yaşayan kişi tıp teknolojisinin ileri düzeyde uygulandığı ihtisas hastanelerine yönlendirilir ve tedavisine burada devam edilir (Kaya,2011: 66). Üniversite hastaneleri gibi eğitim hastaneleri tarafından verilen, ileri tetkik ve özel tedavi gerektiren hastalıklar için düzenlenen, yoğun bilgi ve teknolojiyi içeren sağlık hizmetleridir. Ülkemizde üniversite hastaneleri, sağlık bakanlığı eğitim araştırma hastaneleri, onkoloji hastaneleri, göğüs hastalıkları hastaneleri, çocuk hastaneleri, ruh ve sinir hastalıkları hastaneleri bu tür ihtisas hastaneleridir.

\subsection{Rehabilite Edici Sağlık Hizmetleri}

Sağlık kurumlarında sağlık hizmeti alan sağlığı bozulmuş bireyler tedavi sonrasında kalıcı hasar ile karşılaşabilirler. Bu durum fiziki de olabilir ruhsal da olabilir. Işte bu süreçte kişinin en son haline alışması için rehabilite edilmesi gerekebilir bu durumda beden ve zihin bu alanda senkronize edilmesi için dezavantajlı bireylerin normal bireye döndürülmesi için yapılan sağlık hizmetleri olarak değerlendirilebilir. Rehabilitasyon hizmetleri iki şekilde gerçekleşir. Sosyal rehabilitasyon hizmetleri; psikolojik ve fiziksel açıdan dezavantajı kişinin, normal hayata devam edebilmek için aldığı sağlık hizmetidir. Tıbbi rehabilitasyon ise; kaza veya hastalık sonucu sakat kalan vücut organlarının fizik tedavi ile eski haline getirilmesi olarak açıklanabilir (Atlı ve Yücel,2018).

\subsection{Sağlığın geliştirilmesi hizmetleri}

Tıbbi tedaviler yerinde ve zamanında yapıldığı zaman daha faydalı olabilmektedir. Aksi durumlarda geri dönüşü olmayan yollara girilebilir. Bundan kaynaklı olarak tedavi yöntemlerinde gelişmeler hastalara daha kolay ulaşma ya da yeni bulunan bir tedavi yönteminin geliştirilmesi gibi yenilikleri barındırır sağlığın gelişmesi. Sağılık sektörü her gecen gün teknolojik alt yapının verdiği güvenle gelişmektedir (Aydın,2007). Örnek verecek olursak artık insanlar kollarına taktıkları bir saatle nabızlarını ve vücut aktivitelerini takip edebiliyorlar artık oluşacak bir durumda aile hekimlerine mesaj gidebiliyor. Bu durum sağlıkta kaliteli hizmet olarak tanımlanabilir. Eskiden insanlar hasta olduklarında sağık kuruluşlarına gitmekte zorlanır iken şimdiler de evde sağlık ve bakım hizmetleri ile dezavantajlı gruplara sağlık hizmetleri sunulmaktadır.

\section{Sağlık Kurumlarının Görevleri ve Özellikleri}

Sağlık kurumlarının dört ana görevi vardır. Bunlar incelendiğinde ilk olarak hasta bakımı akla gelmektedir. Hasta bakımı iki şekilde oluşur; ilki tıbbi bakım bu hekimin hastayı tedavi edip tanı koyması süreci, diğeri ise tanı koyulduktan sonraki hasta bakım hizmetleridir.

İkinci görevi; sağlık kurumlarında çalışacak tüm personelin bunların içinde hasta bakıcı, hemşire ve buna benzer görevler teşkil eden personelin eğitim ve uygulama sürecini koordine etmek. Üçüncü görevi: personellerin 
kendilerini geliştirmek adına araştırma ve inceleme yapmasına izin vermek ile kalmayıp bunları desteklemek ve bu noktada teşvik edici olmak.

Dördüncü görevi; sağlık kurumlarına gelen sağ lığını kaybetmiş hastaların ve hasta yakınlarının farklı hastalık ve mikrobiyal hasatlıklara karşı korumak, bulaş olayına engel olmak, hastaların sağlık kurumlarında güvenli hizmet almalarını sağlayarak koruyucu hekimlik rolünü üstlenmektir (Eren,1989:59).

Sağlık kurumlarının amacı insan hayatını kurtarmak korumak, ve insanı yaşatmak aynı zamanda kendi kurumsal yapılarında korumak ve sağlık hizmeti vermeyi engelleyecek bir duruma düşmemektir (Canpolat,2012).

Bunların yanında sağlık kurumları sağlık hizmetleri verirken kaliteli ve güvenli bir hizmet ağı oluşturmak ve de bunu en az maliyet ile en yüksek çıktıyı sağlayarak, sağıı kurumunun faydası maksimize olacak ve de bu durum sağlık işletmesinin güvenli ve kaliteli hizmet ağını her geçen gün artırmasına neden olacak bir sistemin oluşmasına neden olacaktır.

Sağlık hizmeti sunulurken insan ya da cihazlardan yardım alan ve bu sürece dahil ederler. Bu bakımdan yönetim sürecinde planlama, yürütme ve denetleme gibi problemlerin çözümünde multidisipliner bir bakış açısına sahiptirler.Farklı hasta gruplarına 24 saat boyunca farklı sağılı hizmeti verme zorunlulukları vardır. Her hastayla birebir ilgilenmek bireysel tanı ve tedavi sürecini kontrol etmek gibi süreçleri vardır.

Sağlık kurumlarında diğer ticari işletmelerin aksine sunulan hizmetler stoklanamaz ve üretildikleri anda tüketilmek gibi bir durum söz konudur. Bu yüzden tam bir çıktı kontrolü sağlanamaz. Sağlık kurumlarında sunulan hizmetler, insan hayatı için önem taşıması nedeniyle ertelenme gibi bir durum söz konusu olamaz (Canpolat,2012).

\section{Kalite Kavramı}

Bugün birçok sektörde karşımıza çıkan kalite kavramı, insanların bir mal ve hizmete karşı duydukları sağlamlık, güvenilirlik gibi kavramları içinde barındırıken artık kendi başına bir tanım gerektiren bir kavram haline gelmiştir. Kalite geçmişte bir ürün veya hizmetin insanlara ne kadar fayda ve memnuniyet sağlaması iken bugün farklı mal ve hizmeti üretenler ve tüketenler için ayrı ayrı değerlendirilmektedir(Berk,1994).

Kalite her alan için vazgeçilmez bir unsur halini almıştır. Sağlık kurumları ve sağlık hizmeti açısında ise çok ehemmiyetlidir. Çünkü insan hayatı üzerinden hizmet veren ve insana hizmet üreten bir durumdan söz etmekteyiz. Bu bakımdan sağlık kurumlarının kalite yönetimi ilkleri doğrultusunda hizmet etmeleri ve kendilerini bu açıdan geliştirmeleri beklenmektedir(Oksay,2016).

Kalite kavramı M.Ö 2150 yıllarında karşımıza çıkmak da olup oldukça eski bir kavramdır. İlk olarak mısırda yapılan taş blokların sağlamlığının belirli kalite özelliklerine aykırı olması durumunda, bu hatanın tekrarlanması halinde taş blok yapan kişilere ceza uygulaması olarak karşımıza çıkmaktadır. Tarım ile uğraşan toplumlarda ise ürettikleri ürünlerin görsellerine bakarak kalite kontrolü yapılması halk tarafından alışılagelmiş bir durumdur. Yani iri taneli buğday başağı ya da daha cazibeli gözüken elma gibi derecelendirmeler yapılması mümkündür. Sonraki dönemlerde ise teknolojinin gelişim göstermesi kalite denetimini kollara ayrılmıştır. Insanlar bu zaman diliminden sonra ürünün kaliteli olması gerektiğini bir öncelik olarak ele almışlardır. İnsanlar verimliliği artırmak için çeşitli planlamalar yapmışlardır. Bu planları uygulamışlardır ancak bunun kaliteyi düşürdüğünü görmüşler ve bu alanda yetersizlik hissetmişlerdir. Bunun bir sonucu olarak insanlar ürettikleri ürünlerin istatistiklerini tutmuşlardır(Şimşek,2001 : 51 ).

Bu süreç bir süre sonra bazı ürün ve hizmetlerde standartların belirlenmesine üretilen ürünlerin kalite anlayışı çerçevesin de değerlendirilmesine neden olmuştur. Aslında kalite yönetimi tarihsel süreçte bir işletme ve üretim ihtiyacı olarak karşımıza çıkmaktadır. Bu durum her ne kadar doğal gözükmese de iyi ürünlerin kötü ürünlerden ayrılması için bir yol oluşturmuştur. Aynı zamanda rekabet piyasasın varlığıyla bambaşka özellik ve niteliklere kavuşmuştur.

İngiltere'de 1935 yılında İngiliz standartları 600 adı altında bir standartlar dizisi oluşturulmuştur. Bu standartları Japonya bazı önemli sektörlerde kullanmıştır. Daha sonra 1950 yıllarda Japonya kalite kontrol ve istatistiksel yöntemler alanında eğitimler vermeye başlamıştır. Bu gelişmeler Amerika Birleşik Devletlerinin de ilgisini çekmiş ve Japonya ile yapılan birlikte çalışmalar sonucunda Toplam Kalite alanında yeni teknik ve metotlar geliştirmişlerdir(Parlak,2004: 6). 
Bu açıdan bakıldığında kalite kavramının gelişimin üretim ile birlikte geliştiği, teknolojik gelişmeler ile beraberinde ilerlediği gözlemlenmektedir. Innsanoğlu gelişimin her aşamasında daha iyiyi hedeflemektedir işte bu bakımdan kalite hayatımızda var olmuş ve daha iyiye ulaşma cabası var oldukça da var olmaya devam edecektir.

\section{Toplam Kalite Yönetimi ve Illkeleri}

Iş̧letmelerin hizmet ve ya ürün ile ilgili her türlü süreçte kalitenin artırılmasına ve geliştirilmesine yönelik yapılan tüm çalışmaların planlı bir şekilde uygulanarak sistematik bir şekilde ilerleme kaydetmesi ve buna bağlı müşteri memnuniyetini amaçlayan bir yönetim şekli olarak tanımlanabilir toplam kalite yönetimi(Özçakar,2010).

Toplam kalite yönetiminin temelinde dört unsur vardır bunlar; insan, sürekli gelişim, süreç ve müşteridir. Bu bakımdan insan memnuniyeti üst seviyededir. Her şey insanın daha iyi hissetmesi ve daha fazla faydalanması içindir. Bu bakımdan bu alanda çalışanlar insan merkezli bir yapıda tüm benlikleri ile bu amaç için birlikte hareket eden ve varlıklarını bu amaç için ortaya koymuş kişilerdir. Unsurlara değinecek olursak;

İnsan; çalışanların iyi bir ekip oluşturularak maksimum fayda sağlanması amaçlanmaktadır. Sürekli gelişim; Öncelikli olarak iyi bir plan yaparak bunu uygulamak, daha sonra kontrol mekanizmasıyla sonuçları yorumlamak ve sonuç olarak da devamlıı̆ını sağlamak veya değiştirerek baştan planlamak aşamalarından meydana gelir. Süreç; Sürekli gelişimin aşamalarından oluşur.

Müşteri Memnuniyeti; Son ve en önemli unsur müşteridir, Toplam kalite yönetiminin çıkış noktasıdır(Şimşek,2001:89-90).

Toplam kalite yönetimi tüm yönetim kademelerinde aranan bir unsur haline gelmiştir. Bunun nedeni ise kaliteli bir iş ortamı kaliteli bir üretim demektedir. Kalite hayatın her alanında olduğu gibi üretiminde her alanda vardır. Bu süreci çıktısı hizmet olan sektörler bakımında değerlendirildiğinde insan memnuniyetin kalite ile ölçüleceği göz önüne alınırsa ne kadar elzem olduğu gözükebilir.

Toplam kalite yönetimine göre, işletmelerde üretilen mal ya da hizmetin geliştirilmesi, müşteri beklentilerinin maksimum seviyede dikkate alınması maliyetlerinde olabilecek en alt sevilere çekilmesi ana amaç olmalıdır. Bunun gerçekleşmesi için çalışılmalıdır(Yılgör,2000:8).

Toplam kalite yönetimi için gerekli olan unsurlar şunlardır; Liderlik, Müşteri Odaklılık, Herkesin Katılımı ve İletişim, Sürekli İyileştirme, Süreç Yönetimi Önlemeye Dönük Yaklaşım, Sürekli Eğitim ve Öğrenen Organizasyon(Özçakar,2010:108).

Yukarda sıralanan unsurlar toplam kalite yönetimi için gereklidir. Bir kurumda toplam kalite yönetimi süreci etkin ve verimli gerçekleştirilmek isteniyorsa, müşteri odaklı olmalıdır. Aynı zamanda iletişime açık ve sürekli olarak kendisini geliştiren bir örgüt yapısı olmalı ki hizmet kitlesinin ihtiyaçlarını karşılayabilsin bu bağlamda değerlendirme yapmalı ve sağıık hizmetlerinde toplam kalite sürecini değerlendirmelidir.

\section{Sağ|ık Hizmetlerinde Kalite Yönetimi}

Sağlık hizmetlerinde kalitenin ölçülmesi oldukça zordur. Çünkü bireyler kendilerine yapılan tanı ve tedavilerin ne derece kendilerine yarayışlı olduğunu bilecek bilgi beceri ve eğitim seviyesine sahip değillerdir. Bu bakımdan sağık hizmetlerinin değerlendirilmesi kalite açısından kişilere göre zordur(Devebakan ve Aksaraylı,2003:42).

Hizmet sektöründeki büyüme, insan yaşam süresi ortalamasının artması, sağlık sektörünü sürekli teknolojik ve ekonomik olarak gelişmeye zorlamıştır. Buda ülkelerde sunulan sağlık hizmetlerinde kalitenin belirlenmesinde bir faktör haline gelmiştir. Ülkemizde de bu alanda faaliyet gösteren kuruluşlar kalitesini artırmak için çaba sarf etmektedirler. Kalite standartlarını belirlemeye çalışmaktadırlar. İnsanların sağlık hizmeti alırken memnuniyet sevilerini ölçüp sağlıkta kalite standartlarını belirlemeye çalışmaktadırlar. Bu ölçümlerin sürekli yapılarak sağlık kurumlarında kalite yönetim sürecini geliştirmek mümkündür(Yağcı ve Duman,2006:219).

Sağlık hizmetlerinde kalite; uluslararası geçerlilikteki göstergelerde standartlara uygun olarak tanı, tedavi ve bakım hizmetlerinin yanında, bütün hizmet aşamalarında hastaların beklenti ve ihtiyaçlarının eksiksiz karşılanmasıdır (Zorlutuna, 1997). Donebedian sağlık hizmeti kalitesini "Sağlık hizmeti sunumu sürecinde yarar ve zarar dengelerinin yargısı sonucunda oluşan maksimum bir iyileşme beklentisi olarak tanımlamıştır." ve sağlık hizmetlerinde kaliteyi üç temel unsur üzerine kurmuştur. Bunlar (Akalın, 2000); 
Sağlık kuruluşun yapısı (structure)

Sağlık kuruluşunda olagelen işlemler (processes

Sağlık hizmetlerinde elde edilen sonuçlar (outcomes)

Sağlık hizmetlerinde hastaların ve çalışanların memnuniyetinin sağlanması ve mevcut kaynakların en doğru biçimde kullanması modern hizmet sunumu için bir gerekliliktir. Kalite, ürün veya hizmetin, müşteri ihtiyaç ve taleplerini karşılayabilme kapasitesi şeklinde tanımlanırken, sağlık hizmetlerindeki kalite, tanı ve tedavi sürecinin modern tıp bilimine, bilimsel standartlara uygun olmasını ve aynı zamanda verilen hizmetlerin hasta beklentilerini karşılamasını içermektedir (Yıldııım, 2009). Sağlıkta Kalite Standartları'nın ana amaçları hasta ve çalışan memnuniyeti ve güvenliğinin sağlanması, etkinlik ve etkililiğin geliştirilmesi olarak ifade edilebilir. Tüm bu hedeflerin gerçekleştirilmesi halinde sağlık kurumunun başarısı öne çıkabilir. Bu doğrultuda ise kurumun etkinliği ve verimliliği artar Sağlık hizmetleri kişilerin yaşam kalitesini ve mutluluğunu etkilemektedir.

\subsection{Sağlık Hizmetlerinde Kalite Yönetimi Kapsamı}

Sağlık hizmetlerinde toplam kalite anlayışı maliyetleri düşürürken hastalara daha iyi hizmet vermeyi amaçlamaktadır. Eskiden hataları fark edip onları gidermek anlayışı hakim iken toplam kalite yönetiminde bir hata ortaya çıkmasın her türlü olasılık değerlendirilsin diye toplam kalite ekipleri çalışmaktadır.

Sağıık hizmetleri sektöründe maliyetler geri dönülemeyecek sorunlara yol açmaktadır. Bundan ötürü sektörde belli kalıplarda hizmet vermek bu maliyetleri düşürecek aynı zamanda karlıı̆ı artıracaktır. Hata payı azalacaktır. Toplam kalite yönetimi sağlık sektöründe mutlaka uygulanmalıdır. Kalite yönetimi; zaman alan ve inanarak, süreklilik gerektiren bir yönetim şeklidir(Kiymir,1995:317).

Hasta ve hasta yakınlarının memnun olması için sağlık sektöründe hizmet veren kurum ve personel daima en iyinin peşinde olmak zorundadır. Çünkü hastalar daha iyisi varken sizi tercih etmezler. Bundan kaynaklı olarak hem ucuz hem de kaliteli hizmet vermek için çalışmak elzemdir. Bu bakımdan hasta ve yakınlarının memnuniyeti amaçlanmaktadır. Sağlık hizmetlerinde kalite, belirlenen standartlara uygun tanı ve tedavinin yanında, planlanan süreç boyunca hastaların beklentilerinin karşılanmasıdır(Karakılçık,1997:43).

\subsection{Sağlık Hizmetlerinde Kalite Yönetimi Başarısını Belirleyen Etkenler}

Hizmet sektörüne has bir durum olan üretim ve tüketimin aynı anda olması ve tüketicinin üretim aşamasında yer alması üretimin belirli bir standardının olamamasından ötürü kalite kavramının ölçülmesi zorlaşmaktadır(Aydın,2003: 131-132).Toplam kalite yönetiminin sağıık hizmetlerine uyarlanmasında çevresel, örgütsel ve kişilerarası faktörlerin olmasının yanı sıra tesis ve ekonomik faktörlerinde etkili olduğu söylenebilir(Orman,2005).

Çevresel Faktörler: Hastaneler; çıkar grupları fazla olduğu için çevresel faktörlerden etkilenir.

Örgütsel Faktörler: Hizmet sunumunda, eğitim düzeyi düşük personel ile eğitim düzeyi yüksek personel birlikte çaba harcarlar.

Kişilerarası Faktörler: Hastalar olaylara karşı tolerans göstermekte zorlanabilirler. Bu durumlarda hastalar ile kurulan iletişimin olumlu olması sağlanmalıdır.

Tesis Faktörleri: Tedavi hizmetlerinin yanında, tesis olanaklarının da yeterli olması ve son teknoloji cihazlarının kullanılıyor olması müşteri memnuniyeti için oldukça önemlidir.

Ekonomik Faktörler: Kamu hastaneleri başta olmak üzere sağlık kurumlarının sınırlı imkânlarla, verimli bir şekilde çalışarak, amaca yönelik kaliteyi ekonomik bir şekilde sunulmaları beklenmektedir.

\subsection{Sağlık Hizmetlerinde Kalite Yönetimi Uygulamasının Sağlayacağı Yararlar}

Sağlık hizmetlerinde toplam kalite yönetimi uygulamaları çaba gerektiren bir yol olmasına rağmen elde edilen faydalar düşünüldüğünde bu çaba kayda değer bir sonuca dönüşecektir. Toplam kalite yönetiminin faydaları şu şekilde sırlanabilir;

- Genel performansta iyileştirme,

- Çalışanlar arasında ilişkilerin daha iyi düzeye gelmesi,

- Üretkenliğin daha yüksek olması, 
- Hasta memnuniyetinin artması,

- Pazar payındaki artış,

- Karlılı̆ın yükselmesi,

- Laboratuvar tetkik sürelerinin kısalması,

- Radyoloji tekrarlarının azalması,

- Ameliyathane kullanım sürelerinin verimli hale gelmesi,

- Hatalı ilaç verme oranının azalması,

- Hastanelerin hem klinik hem de idari yönde daha kaliteli bir hizmet vermesi,

- İ̧̧ müşterilerin sağlık hizmeti verirken daha kaliteli bir destek hizmeti almalarını sağlamış olacaktır(Benli,2007: 47).

\section{Sonuç}

Sağlık kurumlarında verilen sağlık hizmetleri, insan merkezli bir hizmet olgusudur. Söz konusu insan hayatıdır. Sağlıkları bozulan insanlar tedavi olmak ya da hastalıklarının ne olduğunu öğrenmek için başvururlar sağlık kurumlarına. Bu bağlamda hizmet olgusu yaşanmaya başlanır. Söz konusu hizmet insanların her birine farklı uygulanmak zorundadır çünkü her insanın biyolojik yapısı farklıdır. Ancak uygulama prosedür aynı olabilir. Bir hastaya uygulanan anestezi diğerine uygulanamaz çünkü her hasta yeni bir veri demektir. Bu bağlamda bir standart oluşturmanın zor olduğu görüşü hakimdir tüm bilim dünyasında.

Kalite yönetimi sağlık hizmetlerine uygulanabilirliği zor olmasına rağmen bunun en çok uygulandığı ve verimli sonular alındığı durumlar söz konusudur. Insanlara yapılan hizmetler her ne kadar kişisel olsa da hizmet süreci muhakkak bir kalite yönetimine tabi olmalıdır. Yani uygulanan tedavi sağlık mercilerince kabul edilmiş yanıt oranı yüksek olan bir standarda sahip olmalı denenmiş ve uzun kısa vadeli sonuçları gözlemlenmiş bir yapıda olmalıdır. Bu bakımdan kalite yönetimi sağılk hizmetleri sunulurken kullanılabilir.

Sağlık kurumlarının bir sağlık işletmesi olarak değerlendirmek ona göre de bir kalite standardı oluşturulması gerekmektedir. İşte tam bu noktada bir ameliyathane nasıl olmalı ya da bir poliklinik nasıl olmalı sorularının cevabı kalite yönetimi süreciyle bulunabilir. Çünkü bu noktada hasta memnuniyeti söz konusudur.

Hasta ve hasta yakınlarının memnuniyeti bir sağlık kuruluşu için önem arz etmektedir. Çünkü merkezinde insan olan bir sistemin düzgün çalışmasını en iyi insan taktir edecektir. Bu bakımdan hasta memnuniyeti önemlidir. Hasta memnuniyetini ölçen anketler yapılmalı ve memnuniyet oranları az çıkan yerler ile alakalı eylem planları hazırlanmalı ve uygulanmalıdır.

Tıbbi hataların en fazla olduğu alanlar tespit edilmeli toplam kalite bağlamında verimliliği düşük olan alanlar sistemsel olarak ortaya koyularak yeniden yapılandırılmalı hata oranları düşürülmelidir. Bu bakımdan kalite yönetimi yeni süreçler planlamalıdır.

Kalite yönetimi ayrı bir birim olarak da faaliyet gösterebilir. Ancak yönetim içinde de oluşabilir. Ama en güzeli dış kalite denetimi olarak bilinmektedir. Sağlık kurumları dışından görevlendirilen kalite ekibi oluşabilecek aksaklıkları daha erken fark ederek duygusal davranmadan olayı profesyonel bir şekilde çözümleyecek ve kaliteyi artıracak tedbirler alacaklardır.

Sağlık hizmetlerinde kalite yönetimi demek aynı zamanda hastaların güven endeksleri demektir. Bunu iyi bir hekim transfer ederek sağlamak pek bir kalite yönetimi süreci gerektirmez ancak iyi hekimlerin yetişmesine olanak sağlayacak kalite yönetim süreçlerine izin vermek bu alanda yapılacak ar ge çalışmalarını desteklemek bir kalite yönetim sürecidir. Bunun önemi büyüktür çünkü bu süreçler yeni bir tedavi keşfine kadar giden inovasyon sürecinin önünü açmaktadır.

En başta dediğimiz gibi insan konforu ve rahatı için daha güvende olmak anlayışı içinde yaşam kalitesini bulduğu imkanlar dahilinde hep geliştirmiştir. Sağlık hizmetleri de böyle bir anlayışa sahiptir. Sağılk kurumlarında uygulanmalı ve aktif bir süreç benimsenmelidir.

Sonuç olarak toplam kaliteyi artırmak maliyetleri ilk başta artırsa da kalite artınca karıı̆ı̆ın yükselmesi söz konusu olacağından her zaman için faydalı olacaktır. Toplam kalite uygulaması süreç sonunda yüksek kar maksimizasyonu oluşacak. Pazarda rekabet gücü artacak ve sektörde öncü yol açan konumuna getirecektir sağılık 
kurumlarını ve sağlık hizmetlerini. Çalışma, sağlık kurumlarında kalite yönetimi uygulanması ile sağlanacak yararlar açısından alan yazınına teorik katkı sunacaktır.

\section{Kaynakça}

Akalın, H. E. (2000). Sağlık Hizmetlerinde Sürekli Kalite İyileştirme. Ankem Dergisi, 14(3), 254-257.

Akdur, R.(1999). Türkiye'de Sağlık Hizmetleri ve Avrupa Topluluğu Ülkeleri ile Kıyaslanması, Ankara.

Atlı, Y.-Yücel, N.(2018). Sağılık Kurumları, Sağlık Kurumlarında Marka ve Elazığ illi Sağlık Sektörü, Fırat Üniversitesi iliBF Dergisi, C.2, S.2, Elazığ.

Aydın, S.-Hatırlı, Y.(2003). Birinci Basamak Sağlık Hizmetlerinde Toplam Kalite Yönetimi, Türk Aile Hekimliği Dergisi, C.7, S.3, Ankara.

Aydın, S.(2007). "Sağlığın geliştirilmesi: Görevimizin farkında mııız?", SağılkDüşüncesi ve Tıp Kültürü Platformu, İstanbul, www.sdplatform.com.

Benli, İ. T.(2007). Hastane Süreçleri, Ankara.

Berk, S. O.(1994). Hastanelerde Kalite Sağlama Sistemlerindeki Gelişmeler ve Toplam Kalite Yönetiminin Türkiye'de Uygulanabilirliğine Yönelik Bir Model Önerisi, İstanbul Üniversitesi. SBE, YYLT, İstanbul.

Canpolat, D.(2012). "Hastane Yönetimi”, Mustafa Kemal Üniversitesi Sağlık Yüksekokulu.

Çetin,P.(2015).Türkiye "de Koruyucu Sağlık Hizmetlerinin AB Kriterleri Açısından Bursa Sağlık Kurumları Örneğinde İncelenmesi: Beykent Üniversitesi, Sosyal Bilimler Enstitüsü, İşletme Yönetimi Anabilim Dalı, Yüksek Lisans Tezi,Ankara.

Devebakan, N.- Aksaraylı, M.(2003). “Sağlık İşletmelerinde Algılanan Hizmet Kalitesinin Ölçümünde SERVQUAL Skorlarının Kullanımı ve Özel Altınordu hastanesi Uygulaması”, Dokuz Eylül Üniversitesi SBE Dergisi, C.5, S.1, İzmir.

Erdem, Ş .(2007). Sağlık Hizmetlerinin Pazarlanması: Hastaların Sunulan Hizmetlerin Kalitesini Algılamaları Üzerine Bir Uygulama, Yayımlanmamış Yüksek Lisans Tezi, Trakya Üniversitesi Sosyal Bilimler Enstitüsü, Edirne.

Eren, N.(1989). Sağlık Hizmetlerinde Yönetim, Ankara.

Karakılçık, Y.(1997). Üniversite Araştırma Hastanelerinin Yönetimi, İnönü Üniversitesi SBE, YDT, Malatya.

Kaya,A. (2011).Türkiye Ille Bazı OECD Ülkelerinde Sağlık Sistemleri ve Karşılaştırması: Marmara Üniversitesi, Bankacılık ve Sigortacılık Enstitüsü, Sigortacılık Anabilim Dalı,Yüksek Lisans Tezi,İstanbul.

Kıraç S. A.(2019).,Hizmet Kalitesinin Servqual Modeli ile Ölçülmesi: İstanbul ili Bir Aile Sağlığı Merkezi Örneği, İstanbul Üniversitesi ,Sosyal Bilimler Enstitüsü ,Hastane ve Sağlık Kuruluşlarında Yönetim ,Bilim Dalı ,Yüksek Lisans Tezi, İstanbul.

Kiymir, B.(1995). "Sağlık Kuruluşlarında Kalite Yönetimi- Toplam Kalite Yönetimi” (Ed.) M. Doğan- Ö. Harmancıoğlu- Y. Yeğinboy, 1.Ulusal Sağlık Kuruluşları Ve Hastane Yönetimi Sempozyumu, Dokuz Eylül Üniversitesi, İzmir.

Kurtulmuş, S. (1998). Sağlık Ekonomisi ve Hastane Yönetimi. İstanbul: Değişim Dinamikleri Yayınları. s.84.

Oksay, A.(2016). "Sağlık Hizmetlerinde Kalite Tam Olarak Ne Demek?", Mehmet Akif Ersoy Üniversitesi SABE Dergisi, C.8, S.14, Burdur.

Özçakar, N.(2010). "Bir Kamu Kuruluşundaki Toplam Kalite Yönetimi Uygulamalarının Değerlendirilmesi”, İstanbul Üniversitesi İşletme Fakültesi Dergisi, C.39, S.1, İstanbul.

Parlak, S.(2004).Kalitenin Toplam Yönetimi, İşletmelerde Toplam Kalite Yönetimi.

Sağlık Bakanlığı, Hastane Hizmet Kalite Standartları, Ankara, 2019.

Sert S., (2019) , Türkiye' de Sağlık Sistemi ve Sağlıkta Dönüşüm Programı (2003-2019) , Sağlık Yönetimi Anabilim Dalı, Namık Kemal Üniversitesi,Yüksek Lisans Tezi,Tekirdağ.

Şimşek, M., Kalite Yönetimi, İstanbul, 2001. 
Yağcı, M. I., Duman, T.(2006). Hizmet Kalitesi-Müşteri Memnuniyeti Illişkisinin Hastane Türlerine Göre Karşıllaştırılması, Doğuş Üniversitesi Dergisi, C.7, S.2, İstanbul.

Yıldııım, A. (2009). Sağlık Bakanlığı Hizmet Kalite Standartlarının Hasta Hakları Yönünden İncelenmesi. (Yüksek Lisans Tezi), Kadir Has Üniversitesi, (1).

Yılgör, A. G.(2000). Toplam Kalite Yönetiminin Özel Sektör ve Kamu Kesimi İçin Ortak Bir Model Oluşturabilme Potansiyeli, Iktisat Dergisi, S.405, İstanbul.

Tengilimoğlu D.-Işık 0.-Akbolat M., (2012). Sağlık İşletmeleri Yönetimi, Ankara, s. 69.

Zorlutuna, Y. (1997). Hizmetlerinde Toplam Kalite Yönetimi, Sağlık Hizmetlerinde Devamlı Kalite Iyileştirme: Editör Mithat Çoruh Haberal Eğitim Vakfı. 